University of Nebraska - Lincoln

DigitalCommons@University of Nebraska - Lincoln

Fall 2014

\title{
Climate Change Survey Measures: Exploring Perceived Bias and Question Interpretation
}

Tarik Abdel-Monem

Lisa M. PytlikZillig

Tonya K. Bernadt

Nicole Wall

Follow this and additional works at: https://digitalcommons.unl.edu/lpz

Part of the Administrative Law Commons, Counseling Commons, Dispute Resolution and Arbitration Commons, Family Law Commons, Juvenile Law Commons, Law and Psychology Commons, Law and Society Commons, Psychology Commons, and the Public Law and Legal Theory Commons

This Article is brought to you for free and open access by the Public Policy Center, University of Nebraska at DigitalCommons@University of Nebraska - Lincoln. It has been accepted for inclusion in Lisa PytlikZillig Publications by an authorized administrator of DigitalCommons@University of Nebraska - Lincoln. 


\section{PROJECT MUSE}

\section{Climate Change Survey Measures: Exploring Perceived Bias and}

Question Interpretation

Tarik Abdel-Monem, Lisa M. PytlikZillig, Tonya K. Bernadt, Nicole A. Wall

Great Plains Research, Volume 24, Number 2, Fall 2014, pp. 153-168 (Article)

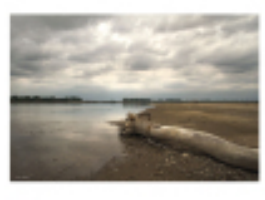

Published by University of Nebraska Press

DOI: https://doi.org/10.1353/gpr.2014.0035

$\Rightarrow$ For additional information about this article https://muse.jhu.edu/article/556157/summary 


\title{
Climate Change Survey Measures Exploring Perceived Bias and Question Interpretation
}

\author{
Tarik Abdel-Monem, Lisa M. PytlikZillig, \\ Tonya K. Bernadt, and Nicole A. Wall
}

\begin{abstract}
Climate change has become an important yet politically divisive topic in recent years. Further complicating the issue are assertions that climate change-related public opinion surveys used by social scientists are biased or otherwise problematic. We conducted a pilot study to explore questions concerning bias and interpretation of climate change surveys. Our study sample was composed of adult residents of Nebraska $(n=115)$. We augmented our survey findings with cognitive interviews of a subsample of respondents $(n=20)$. We assessed study participants' attitudes about climate change, and perceptions of bias and interpretation of survey questions drawn from previously used survey instruments and national polls. Among our study sample, we found little support for perceived bias within the survey items employed. However, interview findings indicated that particular survey language may have elicited unexpected associations among respondents. We discussed implications for further research.
\end{abstract}

Key Words: climate, climate change, public opinion, public understanding, risk communication, science, survey bias

\section{Introduction}

As climatologists work to find ways to measure and track climate change and its effects, social scientists have assessed the changing environment of people's knowledge and attitudes toward climate and climate change. However, less work has been done on the second question than the first, and little attention has been focused on examining the approaches used to gauge public opinion about climate change. The issue is relevant because the discourse about climate policy has become a politically polarized topic. Accusations have become common about the objectivity of climate scientists, the influence of media entities, the role of special interest groups, and other assertions that have complicated the overall discussion (Trumbo 1996; Weingart et al. 2000; Carvalho 2007; Sandell 2007). Concerns have been voiced about climate change public opinion polls becoming part of "framing debates," with frequent assertions that polls or their results are poorly constructed, biased, or mis-

Manuscript received for review, 7/24/13;

accepted for publication, 11/19/13.

Great Plains Research 24 (Fall 2014):153-168. Copyright $\odot 2014$ by the

Center for Great Plains Studies, University of Nebraska-Lincoln reported (Hoffman 2011; Kohut 2010; Krosnick 2010; Solomon 2010). Some of these claims may be closely entangled with partisan commentary about the climate change issue. Others may simply be manifestations of professional disagreement. Regardless, in general there is little empirical basis that informs questions about perceived or actual bias in climate change survey methods.

We conducted a pilot study to explore questions concerning public perceptions of surveys related to climate change. How common is perceived bias of survey questions among the public? What unintended constructs are elicited among respondents in climate change-related surveys? To answer these questions, we employed survey and interview methods using a variety of climate change questions based on previously used survey questionnaires. Our study population was a convenience sample of adults visiting an event at a natural history museum in the state of Nebraska, and the results are thus not necessarily representative of the general population. They may, however, offer insight into the perceptions and thought processes of those members of the public who are, or strive to be, literate in "lay science." Our study results should inform future efforts to further investigate this area. 


\section{Background}

\section{Climate Change}

The global atmospheric concentration of carbon dioxide, methane, and nitrous oxide has increased substantially as a result of industrialization, large-scale agriculture, and sustained fossil fuel use (IPCC 2007). Atmospheric greenhouse gas levels strongly suggest a relationship with corresponding increases in air and ocean temperatures, and widespread glacial and snow cover melting. Mean near-surface temperature has increased $0.76^{\circ} \mathrm{C}$ from the period between 1850 and 1899 to the period between 2001 and 2005, and global sea levels have risen an average of $1.8 \mathrm{~mm}$ per year since 1961 (IPCC 2007). Within the Great Plains, average temperatures have risen $0.9^{\circ} \mathrm{C}$ over the previous 115 years. It is estimated that by 2100 , average temperatures in the region could increase anywhere from $1.6^{\circ}$ to $4.4^{\circ} \mathrm{C}$ (High Plains Regional Climate Center n.d.; US EPA 1998; NCADAC 2013). Average temperature increases might lead to corresponding affects in the prevalence of smog, or increase the likelihood that Lyme disease, encephalitis, or other insect-borne diseases could spread (EPA 1998; IPCC 2007; CDC, EPA, NOAA, and AWWA 2010). Precipitation in the Great Plains will increase in some areas, and decrease in others (GCRP 2009; NCADAC 2013). It is possible that overall ecosystem changes will have considerable social and economic effects throughout the Great Plains (Ojima et al. 2002).

Residents of Nebraska have a major stake in climate change-related outcomes due to its potential impact on the agricultural economy of the state. A warmer climate can result in increased variability and can increase the risks of both floods and droughts (IPCC 2007). Studies on Great Plains states indicated that climate change could significantly impact wheat and corn yields due to shortened crop life cycles (Rosenzweig 1989), the duration of growing seasons, changes in planting dates, seasonal irrigation requirements (Easterling et al. 1993; Karl et al. 2009), and total stream flow in the Missouri River and other basins (Frederick 1993). Increased mean temperatures might also have an impact on animal feed and production rates that would require considerable management changes in the regional livestock industry (Mader et al. 2007). The interaction between natural conditions and human factors, such as employing more groundwater in response to drought, could exacerbate environmental impacts (IPCC 2007).

Climate change could result in both benefits and losses for the agricultural sector, with actual effects contingent on the degree of climate change and effectiveness of mitigation and adaptation efforts (Ojima et al. 2002). Greenstone and Deschenes estimated longterm losses to state agricultural profits in Nebraska of $\$ 670$ million, second only to California at long-term losses of $\$ 750$ million (2006). Another study indicated that for Nebraska, up to $\$ 1.4$ billion in losses to gross domestic product could accrue between 2010 and 2050 as a result of climate change (Backus et al. 2010). Both of these studies converge on the idea that climate change will have a significant impact on Nebraska's economy. In contrast, other studies have found net gains in agricultural production depending on the location, but with considerable adjustment or mitigation costs (Reilly et al. 2003; Kelly et al. 2005).

\section{Public Opinion on Climate Change}

Early international efforts to gauge public views on global warming included the 1989 Harris and Associates survey on global environmental issues, conducted for the United Nations Environmental Programme (Harris and Associates 1989), and the Gallup Health of the Planet survey (Dunlap et al. 1993), which coincided with the 1992 United Nations Conference on Environment and Development (Brechin 2003). Further opinion research was conducted as public awareness of climate change increased in the 1990s. Important early efforts examined the public's understandings of climate change causes and effects (Bostrom et al. 1994; Read et al. 1994) and associated value judgments (Kempton 1991; Kempton et al. 1996). Early survey research efforts found that the public tends to believe that climate change is occurring as a result of human activity and views it as an important problem, but generally lacks detailed understandings of cause and effect models (Kempton 1997; Kempton et al. 1996), climate change processes, and climate science (Kasemir et al. 2000; Morgan et al. 2001).

Within the United States, researchers have conducted a number of opinion surveys on climate change using national samples. Primary examples of academic research on national public opinion of climate change include work affiliated with the Stanford Woods Institute for the Environment (Krosnick et al. 2000; Malka et al. 2009; Villar and Krosnick 2011) and the Yale Climate and Energy Institute and Yale Project on Climate Change Communication (Leiserowitz 2004, 2005, 2006; Leiserowitz and Smith 2010; Leiserowitz et al. 
2010). However, there are fewer studies of survey research specifically targeting midwestern or Great Plains populations about climate change. Examples include Diggs's survey of dryland farmers in North Dakota and northern Colorado to assess decision-making behavior related to climate change (Diggs 1991), the Energy Center of Wisconsin's nine-state study of perceptions of energy and climate change issues in the Midwest (Energy Center of Wisconsin 2008), Hamilton and Keim's study of climate change attitudes in rural areas (2009), and a 2008 study by Vogt and colleagues on rural Nebraskans' perceptions of climate change. Not unlike national polls, the Vogt study found that a majority of rural Nebraskans are concerned about climate change (60\%), believe it is happening (58\%), and that it is caused by human activity (65\%).

Previous opinion studies conducted in various regional contexts indicate that respondent characteristics may be associated with perceptions and attitudes toward climate change, though the relationship is complex and unclear. For example, associations have been suggested between perceptions of climate change and socioeconomic characteristics (Bord et al. 1998; O'Connor et al. 2002; Wood and Vedlitz 2007), cultural and social values (Kahan et al. 2007; Braman et al. 2011), state residence (Shwom et al. 2008), and recent experiences with weather (Joireman et al. 2010; Spence et al. 2011; Egan and Mullin 2012). Several polls have suggested that political and social conservatives are less concerned about climate change and/or are less supportive of policies aimed at addressing climate change (Leiserowitz 2005; Krosnick et al. 2006; Dietz et al. 2007; McCright and Dunlap 2011). For example, Hamilton and Keim (2009) found that both Republican party identification and participation in religious services reduced the likelihood of recognizing climate change effects. National public opinion polls also regularly show that there are major partisan differences in perceptions, with selfidentified Republicans or conservative-leaning individuals being significantly less likely than Democrats or liberals to believe that human activity is causing climate change (Pew Research Center 2010, 2012). This ideological divide is well acknowledged in current policy discourse and is reflected in the official platforms of both national parties (Democratic National Committee 2012; Republican National Committee 2012).

Public attention has focused on allegations of bias within climate change science or climate changerelated surveys. Many-though not all-of these debates, tend to have sharp partisan or ideological implications. For instance, assertions are frequently made alleging a politically liberal tendency among the climate science community. In support of these assertions are studies indicating that climate or natural scientists tend to identify as politically liberal (Pew Research Center 2009b; Rosenberg et al. 2010). Some climate scientists have alleged to have felt pressure to filter or exaggerate climate data (Lichter 2008). Reports in the media and other commentary have also alleged examples of potential or real conflicts of interest among climate scientists (Morello 2009; Pexton 2012). Within this context, assertions have been made that some climate public opinion surveys are intentionally biased or politically motivated. As opposed to critique aimed at sampling errors or selection bias, commentators have argued that opinion survey language itself may be deliberately leading in order to generate results that support policy positions on climate (Harris 2012; Pielke 2012).

Examining perceptions of bias in climate change survey questionnaires is important for several reasons. From a methodological perspective, an obvious concern exists regarding the face and content validity of surveys, and their implications for relevance, reliability, and interpretive value. These are general concerns that are not topically specific to climate change survey instruments in particular, and have been discussed elsewhere (Fowler 1995, 2008; Litwin 1995). Second is the interest in developing an empirical basis examining if, or the extent to which, people perceive climate change survey instruments as biased. Because of the politically charged discourse surrounding climate change, an empirical rather than anecdotal foundation can be valuable in providing transparency and guidance around questions of bias or undue influence on respondent answers. This is important because questions of trust and credibility have become distractions to the issue of climate change generally (Leiserowitz et al. 2012; Maibach et al. 2012). Third is the general interest in advancing cognitive science related to public understanding and thinking about climate change. Fourth-and related to each of the previous concerns-is the interest in informing an agenda for climate and public opinion science that is ethical, responsive, and provides value to stakeholders.

\section{Methods}

We explored perceptions of climate change survey items among a sample of adult Nebraskans. The survey 
items examined were used previously in other climate change public opinion surveys verbatim or based on modified versions. Our pilot study was composed of individuals who attended a public science event called Dinosaurs and Disasters, held at the State Museum in Lincoln, Nebraska, in February 2012. We used a cognitive interview process augmented with a survey of our convenience sample to learn about perceptions of both climate change and the climate change survey items we asked them. Although our research focused on this subsample of residents of Nebraska and may not yield widely generalizable results, it does provide insight into some Nebraskans' perceptions and interpretations of climate change survey items used in previously conducted national polls. Beyond this principal inquiry, we were interested in knowing to what extent local concerns or issues experienced in the regional contextfor example, drought-might be relevant to our study participants. Additionally, because of the assumption that our sample may be "lay scientific literate" as science museum attendees, we were interested in exploring the extent to which concerns about bias in climate science may resonate with them at all.

Prior to choosing the items for the survey in this study, we examined 17 climate change-related questionnaires to review how other researchers were assessing knowledge, attitudes, and behaviors. This review included both national studies by public opinion research firms such as Pew (2009a, 2009c), as well as a sample of surveys in academic literature which were relevant to our research interests. The review was not meant to be a comprehensive analysis of climate change-related survey instruments or measures, but rather an overview to identify what general constructs were assessed by commonly referenced surveys. Working independently, we first worked in two sets of pairs and coded a subset of survey items and categorized them under five constructs: (1) questions about attitudes, (2) behaviors, (3) beliefs, (4) knowledge, and (5) policy preferences regarding the climate or climate change. These categories were major constructs identified by us using a coding and classification approach that were shared across multiple surveys we reviewed (Glaser 1978; Strauss and Corbin 1990). Each pair of coders agreed on a common category for $92 \%$ of the survey items reviewed. We then reviewed all items and discussed items with which there were initial disagreements, and came to decide on the final classification of items by unanimous consensus. Source citations of the surveys reviewed are listed in the appendix.

Next, we constructed a paper survey questionnaire that featured eight substantive questions related to the climate or climate change. We intentionally chose to include items in the questionnaire that spanned four out of five of our major categories of survey item constructs identified in the review phase-attitudes, behaviors, beliefs, and knowledge-and represented a diverse mix of topical content related to climate change. To mitigate the possibility of generating overtly partisan reactions to our questionnaire, we omitted measures that fell under the policy preferences category. Three of the questions and their response categories we used were borrowed verbatim from either the 2004 national public survey conducted by Texas A\&M University's Institute for Science, Technology, and Public Policy (Vedlitz et al. 2008) or from the 2010 national public survey conducted by the Yale Project on Climate Change Communication (Leiserowitz et al. 2010). Three of the remaining questions were slight adaptations of measures used in either the Texas A\&M or Yale Project surveys, the 2008 survey of rural Nebraskans conducted by the University of Nebraska-Lincoln's Center for Applied Rural Innovation (Vogt et al. 2008), or the May 2009 national public survey conducted by the Pew Research Center for the People and the Press on science (Pew Research Center for the People and the Press 2009a). We modified these questions for purposes of brevity, or to create uniform response categories. A remaining question was used from the Nebraska rural survey but paired with response categories from the Pew survey. We created a final substantive measure on the topic of perceived risks of drought in the Great Plains due to its local relevance. Questions used, their identified construct, and their source references are presented in Figure 1. At the end of the survey, participants were asked to rate their agreement (on a 1 to 5 , strongly disagree to strongly agree, scale) with six statements designed to gauge general impressions of the survey, survey experience, and one's subjective knowledge (see Table 1 for items). 
FIGURE 1. Survey questions and sources.

Question 1 (Beliefs). Which of the following best describes your views about climate change?*

Climate change is happening mostly because of natural changes in the atmosphere.

Climate change is happening mostly because of human activity such as burning fossil fuels.

Climate change is happening equally because of human activity and natural changes.

Climate change is happening but there is not enough evidence to determine its cause.

Climate change is not happening.

(Source: Pew 2009a; Vogt et al. 2008)

Question 2 (Attitudes). I am very concerned about global warming and climate change. ${ }^{* *}$

Strongly agree $>$ Agree $>$ Slightly agree $>$ Slightly disagree $>$ Strongly disagree, Don't know

(Source: Vedlitz et al. 2008)

Question 3 (Attitudes). To what extent do you feel concerned about climate change affecting: (your family, community, Nebraska, United States, other countries)?***

$\begin{array}{ll}\text { Your family } & \text { United States } \\ \text { Your community } & \text { Other countries } \\ \text { Nebraska } & \end{array}$

Nebraska

(Source: Vogt et al. 2008)

Question 4 (Attitudes). How concerned, or worried, are people in your social network about the issue of global warming and climate change, using a scale of o to 10 where $o$ is not concerned at all and 10 is extremely concerned. ${ }^{\dagger}$

(Source: Vedlitz et al. 2008.)

Question 5 (Behavior). My actions to reduce the effects of global warming and climate change in my community will encourage others to reduce the effects of global warming through their own actions. ${ }^{* *}$

Strongly agree $>$ Agree $>$ Slightly agree $>$ Slightly disagree $>$ Strongly disagree, Don't know

(Source: Vedlitz et al. 2008)

Question 6 (Beliefs). The Great Plains have been subject to many prolonged droughts over the years (e.g., the "Dust Bowl" of the 1930s, the 1950s, and most recently in the Southern Plains states). Do you think the severity and length of droughts will continue to increase (even beyond the major historical events) due to climate change?

Yes

No

Unsure

(Source: Authors)
Question 7 (Behavior). Please indicate whether you do any of the following things: Always, Often, Rarely, or Never. ${ }^{\dagger}$

Car pool

Walk or ride a bike instead of driving a car

Use public transportation

Turn off lights and appliances when not in use

Recycle

Set the thermostat lower in winter and higher in summer

(Source: Vedlitz et al. 2008)

Question 8 (Knowledge). People disagree about how the climate system works. The five pictures below illustrate five different perspectives. Each picture depicts the Earth's climate system as a ball balanced on a line, yet each one has a different ability to withstand human-caused global warming. Which one of the five pictures best represents your understanding of how the climate system works?'

Gradual

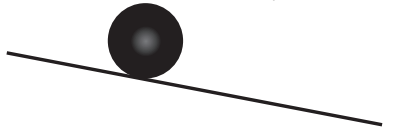

Earth's climate is slow to change. Global warming will gradually lead to dangerous effects.

Fragile

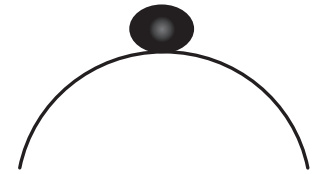

Earth's climate is delicately balanced. Small amounts of global warming will have abrupt and catastrophic effects.

Stable

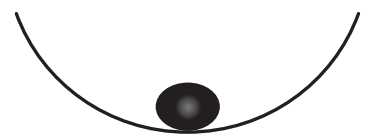

Earth's climate is very stable. Global warming will have little to no effects.

\section{Threshold}

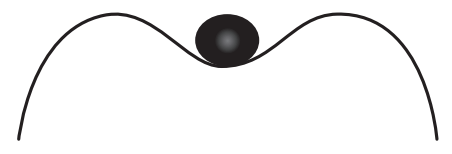

Earth's climate is stable within certain limits. If global warming is small, climate will return to a stable balance. If it is large, there will be dangerous effects.

Random

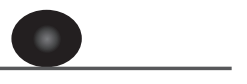

Earth's climate is random and unpredictable.

Source: Leiserowitz et al. 2010.

${ }^{\star}$ Question statement modified from Vogt et al. (2008), with substitution of "global climate change" for "climate change." Response categories adapted from Pew (2009b).

** Response categories broadened to include "Slightly agree" and "Slightly disagree."

${ }^{* * *}$ Question statement modified from "How concerned are you about the possibility of global climate change impacting the following groups?"

†Reproduced verbatim from cited source.

*Developed by authors. 
In addition, we used a $2 \times 2$ experimental design in which we randomly varied whether or not people received a page of brief definitions (e.g., defining weather versus climate, climate change, climate variability, and climate impacts) and whether or not people were asked to explain their answers to the eight survey questions (using the prompt "If you are willing, please indicate why you answered as you did" after each question). These manipulations were included in order to determine whether or not such instructions impacted people's perceptions of the survey. Unfortunately, observations and actual surveys indicated that many participants did not read the definitions when they received them, and did not write explanations when asked. Because we also found no significant or marginal main or interactive effects of these experimental conditions on any of the variables in this study, we do not discuss them further. For example, $2 \times 2$ univariate analyses of variance (ANOVAs) found no significant or marginal main or interactive effects of reading or not reading definitions relating to climate change and writing or not writing explanations for one's answers (all $F s(3,81)<2.50$, $p s>$ .10 , partial $e t a^{2} \leq .030$ ).

We invited interested individuals to participate in the survey about climate change at the museum event. A total of 115 individuals completed the survey. All respondents were also asked if they would participate in an interview until a targeted quota of 20 interviewees was filled. As an incentive, we gave a free notebook to those survey participants who agreed to be interviewed. We provided interested individuals with study consent materials that were approved by the University of Nebraska-Lincoln Institutional Review Board prior to participation. We conducted interviews in a quiet area of the museum, and recorded those interviews with participant consent.

Our interview questions were based on a cognitive interviewing approach. Cognitive interviewing is a widely used method developed by psychometrics researchers to examine and improve survey instruments, and has been discussed at length in survey methodology literature (Tourangeau 1984; Jobe and Mingay 1991; DeMaio and Rothgeb 1996). Cognitive interviewing essentially involves asking study participants a series of probing questions about survey items in a controlled environment to examine their understanding and processing of items and responses (Forsyth and Lessler 1991; Oksenberg et al. 1991). We were interested in understanding the respondents' comprehension and interpretation of the survey items, decision processes behind question responses, perceptions of whether survey items were biased or in need of improvement, and respondent biases that may have been activated by the questions. Interview questions are presented in Figure 2. Interviewers were randomly assigned to interviewees.

FIGURE 2. Interview questions.

1. Tell me a little bit about what you thought as you answered this question. What went through your mind when you read it, or your reaction to the question as you read it?

2. Tell me why you chose to answer the question the way you did.

3. The questions refer to things happening due to climate change. What did those words mean to you? How do you interpret the words climate change and global warming?

4. What have you heard, or what experiences have you had that influenced your answer to this question?

5. Would you change this question in any way? Was there anything about this question that was confusing or unclear or biased?

\section{Results}

\section{Survey Results}

We analyzed data from the survey using SPSS v.21, and, when relevant, statistical significance was evaluated at the $p<.05$ level. Of the 115 adults who participated in the paper questionnaire, a clear majority $(85 \%, n=98)$ indicated that they were concerned about global warming and climate change. Nearly half the respondents indicated that they believed climate change was occurring because of an equal mix of human activity and natural causes $(48 \%, n=55)$. Twenty-eight percent $(n=32)$ believed it was occurring mostly because of human activity, and $15 \%(n=17)$ believed it was occurring mainly because of natural factors. Only $10 \%(n=11)$ of the questionnaire sample believed that either climate change was not happening or, if it was happening, believed there was not enough evidence to indicate its cause. On a scale of $1-4(1=$ not concerned, $4=$ very concerned $)$, respondents indicated that they felt the most amount of concern about the impacts of climate change on other countries $(\mathrm{M}=2.75 \mathrm{SD}=.974)$, followed by concern about impacts on the United States $(\mathrm{M}=2.68 \mathrm{SD}=.879)$, Nebraska $(M=2.54 \mathrm{SD}=.853)$, their community $(\mathrm{M}=$ 
$2.53 \mathrm{SD}=.885)$, and their family $(\mathrm{M}=2.5 \mathrm{SD}=.934) . \mathrm{Ex}-$ amination of the data using paired $t$-tests revealed that concern about impacts on one's family, community, and Nebraska were each significantly lower than concern about impacts on the United States or other countries, $d f s=112-113, t s>2.74, p s<.01$. However, there were no significant differences between concern about impacts on one's family, community, and Nebraska. The difference between concern about impacts on the United States and other countries also was not significant. Thus, the more local the target of concern, the less concern they expressed. We also asked respondents to assess their overall level of concern, and the level of concern among their social networks toward global warming and climate change. On a scale of $1-6(1=$ strongly disagree, $6=$ strongly agree, that "I am very concerned about global warming and climate change"), the average overall concern was $4.5(\mathrm{SD}=1.14)$. On a scale of $\mathrm{o}-10$ (o $=$ not concerned at all, $10=$ extremely concerned), the average perceived level of concern among their social networks was $4.9(\mathrm{SD}=2.36)$. All results from the main survey questions are presented in Figure 3.

In Table 1, we report the results from the questions about the survey, survey experience, and subjective knowledge. As shown, $7 \%$ percent of respondents ( $n=$ 7 ) indicated that they agreed with the statement "This survey seemed biased," $60 \%(n=65)$ disagreed with the statement, and $33 \%(n=36)$ remained neutral. Table 1 (rightmost columns) also shows the correlations between one's own overall concern or the concern perceived in one's social networks and questions assessing impressions of the survey. The correlations between one's own concern $(r=-.18, p=.064)$ or the perceived concern of one's social network about climate change ( $r=-.07, p=.498)$, and the rating of perceived bias in the survey, were small and did not achieve statistical significance. Examination of the data categorically also confirmed that individuals who agreed that they were concerned about global warming and climate change were approximately equally as likely as those that did not agree, to perceive that the survey was biased $\left(\mathrm{X}^{2}(1)=\right.$ $2, p=.157)$. We found very similar results when examining the other statements related to bias ("I think that the survey designers had ulterior motives" and "This survey seemed like a good way to measure people's views on this topic"). Very few participants thought the survey designers had ulterior motives or that the survey was not a good way to measure people's views, and answers to these questions were not significantly related to either one's own or one's social network's concern about climate change and global warming. In fact, only two correlations were significant: the correlation between appreciation about being able to give their views and personal concern about climate change, and between one's subjective knowledge and one's perception that one's social network was concerned about climate change. Interestingly, having high subjective knowledge did not correlate with one's own reported concern.

\section{Interview Results}

We transcribed and reviewed all 20 interviews using a constant comparative approach to identify themes relevant to our research questions (Strauss 1987; Strauss and Corbin 1990). The interviews provided us with an opportunity to explore, beyond the paper questionnaire, the attitudes and beliefs of participants in regard to these issues.

\section{Respondent Perceptions of Bias in the Survey}

None of the 20 individuals we interviewed indicated that they felt specific items were biased, unfair, or leading. Almost all interviewees believed that the questions were clear and affirmatively stated that they raised no concerns. Most interviewees simply stated that the survey questions were "good" or "seemed solid." Two interviewees alluded to bias in surveys more generally; both indicated that they were skeptical of human-caused climate change. This may indicate that belief in causes of climate change may influence how they perceive the validity of surveys:

I was anticipating that answers would skew towards man-made issues, but they actually didn't. I chose [response] A-that it's caused by natural causes.

In other [surveys], scientists seem to turn questions towards their thoughts. We have a lot of historical climate change occurrences before people were even on the planet, so humans weren't the cause of prior ones. There's a lot of stuff coming out of volcanos so it just makes sense to me that it's natural.

It is important to note that besides these two references, there were no indications that specific language or response categories of the questions were of concern to the interviewees. However, it is noteworthy that of the interviewees that did acknowledge the possibility of bias, both indicated that they had doubts about human causation of climate change. 
FIGURE 3. Paper survey results.

Q1. Which of the following best describes your views about climate change?

\begin{tabular}{l|l}
\hline $\begin{array}{l}\text { Climate change is happening mostly } \\
\text { because of natural changes in the } \\
\text { atmosphere. }\end{array}$ & $15 \%, 17 / 115$ \\
\hline $\begin{array}{l}\text { Climate change is happening mostly } \\
\text { because of human activity such as } \\
\text { burning fossil fuels. }\end{array}$ & $28 \%, 32 / 115$ \\
\hline $\begin{array}{l}\text { Climate change is happening equally } \\
\text { because of human activity and natu- } \\
\text { ral changes. }\end{array}$ & $48 \%, 55 / 115$ \\
\hline $\begin{array}{l}\text { Climate change is happening, but } \\
\text { there is not enough evidence to deter- } \\
\text { mine its cause. }\end{array}$ & $9 \%, 10 / 115$ \\
\hline \begin{tabular}{l} 
Climate change is not happening. \\
\hline
\end{tabular} & $1 \%, 1 / 115$ \\
\hline
\end{tabular}

Q2. I am very concerned about global warming and climate change.

$\mathrm{M}=4.5, \mathrm{SD}=1.135, n=113$

( 1 = Strongly disagree, 6 = Strongly agree $)$

Question 3. To what extent do you feel concerned about climate change affecting...

\begin{tabular}{l|l}
\hline Your family & $\mathrm{M}=2.5, \mathrm{SD}=.934, n=114$ \\
\hline Your community & $\mathrm{M}=2.53, \mathrm{SD}=.885, n=114$ \\
\hline Nebraska & $\mathrm{M}=2.54, \mathrm{SD}=.853, n=114$ \\
\hline United States & $\mathrm{M}=2.68, \mathrm{SD}=.879, n=113$ \\
\hline Other countries & $\mathrm{M}=2.75, \mathrm{SD}=.974, n=114$ \\
\hline $\begin{array}{l}\text { (1= Not concerned, } 4= \\
\text { Very concerned) }\end{array}$ & \\
\hline
\end{tabular}

Q4. How concerned, or worried, are people in your social network about the issue of global warming and climate change, using a scale of 1 to 10 where $o$ is not concerned at all and 10 is extremely concerned.

$\mathrm{M}=4.88, \mathrm{SD}=2.36, n=113$
Q5. My actions to reduce the effects of global warming and climate change in my community will encourage others to reduce the effects of global warming through their own actions.

\begin{tabular}{l}
$\mathrm{M}=4.17, \mathrm{SD}=.932, n=108$ \\
$(1=$ Strongly disagree, $6=$ Strongly agree $)$ \\
\hline
\end{tabular}

Q6. The Great Plains have been subject to many prolonged droughts over the years (e.g., the "Dust Bowl" of the 1930s, the 1950s, and most recently in the Southern Plains states). Do you think the severity and length of droughts will continue to increase (even beyond the major historical events) due to climate change?

\begin{tabular}{l|l}
\hline Yes & $51 \%, 56 / 111$ \\
\hline No & $11 \%, 12 / 111$ \\
\hline Unsure & $39 \%, 43 / 111$ \\
\hline
\end{tabular}

Q7. Please indicate whether you do any of the following things:

\begin{tabular}{l|c|c|c|c}
\hline & Never & Rarely & Often & Always \\
\hline Car pool & $\begin{array}{c}19 \% \\
21 / 112\end{array}$ & $\begin{array}{c}49 \% \\
55 / 112\end{array}$ & $\begin{array}{c}26 \% \\
29 / 112\end{array}$ & $\begin{array}{c}6 \% \\
7 / 112\end{array}$ \\
\hline $\begin{array}{l}\text { Walk or ride a } \\
\text { bike instead of } \\
\text { driving a car }\end{array}$ & $17 \%$ & $52 \%$ & $29 \%$ & $2 \%$ \\
\hline $\begin{array}{l}\text { Use public } \\
\text { transportation }\end{array}$ & $55 / 111$ & $58 / 111$ & $32 / 111$ & $2 / 111$ \\
\hline $\begin{array}{l}\text { Turn off lights } \\
\text { and appliances }\end{array}$ & $1 \%$ & $45 / 105$ & $2 / 105$ & $3 / 105$ \\
$\begin{array}{l}\text { when not in } \\
\text { use }\end{array}$ & $111 \%$ & $24 \%$ & $74 \%$ \\
\hline $\begin{array}{l}\text { Recycle } \\
\text { fer }\end{array}$ & $4 \%$ & $10 \%$ & $36 \%$ & $51 \%$ \\
$\begin{array}{l}\text { Set the ther- } \\
\text { mostat lower } \\
\text { in winter and } \\
\text { higher in } \\
\text { summer }\end{array}$ & $1 / 112$ & $7 / 112$ & $45 / 112$ & $59 / 112$ \\
\hline
\end{tabular}


Q8. People disagree about how the climate system works. The five pictures below illustrate five different perspectives. Each picture depicts the Earth's climate system as a ball balanced on a line, yet each one has a different ability to withstand human-caused global warming. Which one of the five pictures best represents your understanding of how the climate system works?

\begin{tabular}{|c|c|}
\hline $\begin{array}{l}\text { Gradual } \\
\text { Earth's climate is slow to change. Global warm- } \\
\text { ing will gradually lead to dangerous effects. }\end{array}$ & $\begin{array}{c}24 \% \\
26 / 108\end{array}$ \\
\hline $\begin{array}{l}\text { Fragile } \\
\text { Earth's climate is delicately balanced. Small } \\
\text { amounts of global warming will have abrupt } \\
\text { and catastrophic effects. }\end{array}$ & $\begin{array}{c}17 \% \\
18 / 108\end{array}$ \\
\hline $\begin{array}{l}\text { Stable } \\
\text { Earth's climate is very stable. Global warming } \\
\text { will have little to no effects. }\end{array}$ & $\begin{array}{c}6 \% \\
6 / 108\end{array}$ \\
\hline $\begin{array}{l}\text { Threshold } \\
\text { Earth's climate is stable within certain limits. If } \\
\text { global warming is small, climate will return to a } \\
\text { stable balance. If it is large, there will be danger- } \\
\text { ous effects. }\end{array}$ & $\begin{array}{c}40 \% \\
44 / 108\end{array}$ \\
\hline $\begin{array}{l}\text { Random } \\
\text { Earth's climate is random and unpredictable. }\end{array}$ & $\begin{array}{c}13 \% \\
14 / 108\end{array}$ \\
\hline
\end{tabular}

\section{Global Warming versus Climate Change}

Several of the survey questions we asked made direct reference to the terms "global warming" and/or "climate change." Climate scientists, policy makers, media entities, and others have made use of both terms historically, and some degree of discussion exists as to the appropriateness of each term and their accuracy and relevance to discussions of bias (Schumacher-Matos 2011). During the interviews, we probed for whether or not interviewees distinguished between the two terms, and found that the words elicited a very wide variety of associations and thoughts, some that possibly implied inaccurate understanding.

Three interviewees indicated that global warming referred specifically to increasing atmospheric tempera-

\begin{tabular}{|c|c|}
\hline \multicolumn{2}{|c|}{ Gender } \\
\hline \multirow[t]{2}{*}{ Female } & $63 \%$ \\
\hline & $69 / 109$ \\
\hline \multirow[t]{2}{*}{ Male } & $37 \%$ \\
\hline & $40 / 109$ \\
\hline \multicolumn{2}{|c|}{ Education } \\
\hline \multirow[t]{2}{*}{ Less than high school } & $1 \%$ \\
\hline & $1 / 111$ \\
\hline \multicolumn{2}{|l|}{ Some high school, no diploma } \\
\hline \multirow[t]{2}{*}{ High school graduate } & $2 \%$ \\
\hline & $2 / 111$ \\
\hline \multirow[t]{2}{*}{ Some college, no degree } & $21 \%$ \\
\hline & $23 / 111$ \\
\hline \multirow[t]{2}{*}{ Associate's degree } & $15 \%$ \\
\hline & 17 / 111 \\
\hline \multirow[t]{2}{*}{ Bachelor's degree } & $30 \%$ \\
\hline & $33 / 111$ \\
\hline \multirow[t]{2}{*}{ Some graduate school } & $11 \%$ \\
\hline & $12 / 111$ \\
\hline \multirow[t]{2}{*}{ Graduate or professional degree } & $21 \%$ \\
\hline & $23 / 111$ \\
\hline
\end{tabular}

tures, whereas climate change was a broader phenomenon that described other climatic changes in addition to temperature increase. This distinction is generally considered to be scientifically accurate (NASA 2008):

I think global warming came about because the average temperature was increasing, and that was mostly true, but there are some places where temps were actually decreasing. And climate change was a more appropriate term from what I understand. So it's the same thing but rebranded.

Global warming is what they are talking about with the greenhouse gases, and they are worried with the chlorofluorocarbons. ... Climate change [is when] they are talking about the planet as a whole, not just 
TABLE 1. Percentage responses to perception of survey questions, and correlations with concern (Questions Q2 and Q4).

\begin{tabular}{|c|c|c|c|c|c|c|c|c|}
\hline Item & $\begin{array}{c}\text { Strongly } \\
\text { disagree } \\
(1)\end{array}$ & $\begin{array}{c}\text { Disagree } \\
\text { (2) }\end{array}$ & $\begin{array}{c}\text { Neither / } \\
\text { Neutral } \\
\text { (3) }\end{array}$ & $\begin{array}{l}\text { Agree } \\
(4)\end{array}$ & $\begin{array}{l}\text { Strongly } \\
\text { agree } \\
(5)\end{array}$ & $\begin{array}{c}\text { Mean } \\
(\mathrm{sD})\end{array}$ & $\begin{array}{l}\text { Correlation } \\
\text { with own } \\
\text { concern } \\
(1-6 \text { scale })\end{array}$ & $\begin{array}{c}\text { Correlation } \\
\text { with network } \\
\text { concern } \\
(0-10 \text { scale })\end{array}$ \\
\hline This survey seemed biased. & $14 \%$ & $46 \%$ & $33 \%$ & $6 \%$ & $1 \%$ & $\begin{array}{l}2.33 \\
(.82)\end{array}$ & -.18 & -.07 \\
\hline $\begin{array}{l}\text { I think that the survey de- } \\
\text { signers had ulterior motives. }\end{array}$ & $16 \%$ & $39 \%$ & $38 \%$ & $6 \%$ & $1 \%$ & $\begin{array}{l}2.36 \\
(.85)\end{array}$ & -.16 & -.02 \\
\hline $\begin{array}{l}\text { This survey seemed like a } \\
\text { good way to measure people's } \\
\text { views on this topic. }\end{array}$ & $1 \%$ & $3 \%$ & $26 \%$ & $61 \%$ & $9 \%$ & $\begin{array}{l}3.75 \\
(.70)\end{array}$ & .08 & -.04 \\
\hline $\begin{array}{l}\text { I appreciated being able to } \\
\text { offer my views on this topic. }\end{array}$ & $2 \%$ & $2 \%$ & $24 \%$ & $55 \%$ & $18 \%$ & $\begin{array}{r}3.85 \\
(.80)\end{array}$ & $.26^{\star *}$ & .12 \\
\hline $\begin{array}{l}\text { While taking this survey, I } \\
\text { learned something I did not } \\
\text { know before. }\end{array}$ & $6 \%$ & $28 \%$ & $35 \%$ & $27 \%$ & $5 \%$ & $\begin{array}{l}2.97 \\
(.99)\end{array}$ & .13 & -.09 \\
\hline $\begin{array}{l}\text { I am very knowledgeable } \\
\text { about climate science. }\end{array}$ & $5 \%$ & $40 \%$ & $35 \%$ & $19 \%$ & $1 \%$ & $\begin{array}{r}2.71 \\
(.86)\end{array}$ & .14 & $.20^{*}$ \\
\hline
\end{tabular}

Note: $N=105-110$ (listwise $N=102$ ) depending on the question, ${ }^{*} p<.05,{ }^{* *} p<.01$.

the atmosphere, but the ocean and sea temperature. It is physical, I have seen them. Global warming is just the gases in the atmosphere.

Yes, because I think there are different types of climate change that are not just global warming. So, they interact with one another and overlap, but I would see them as different things.

In contrast, an approximately equal amount of interviewees acknowledged that the two terms had different meanings but did not offer specific definitions to distinguish between the two terms, or they gave explanations that suggested misconceptions about climate change and global warming:

It is kind of similar, not the same. They are in a category together. They have to do with each other.

I think they are separate, global warming is more natural.

This indicates the possibility that there is awareness of the different terms but a lack of clarity as to what phe- nomenon they refer to. One individual noted that both terms refer to the same phenomenon, but that use of these terms by the media has changed over time:

I see climate change as the new PC term for global warming. I think it's a change in terms. It was always climate change or always on a grander scale, not well understood. People labeled it global warming and the media is choosing to call it [climate change] late. It's getting out more as climate change.

These results indicate some degree of variation exists in how the terms "global warming" and "climate change" are understood or interpreted. Some individuals may have little understanding of the phenomena referred to by these terms, and that use of these terms evokes a wide variety of associations that are likely to impact participant responses. For example, one interviewee indicated having the following political and religious associations with the terms:

First thing I think of is Al Gore. I think of the glaciers and people in Antarctica talking about an ice 
shelf falling off. I am not concerned the earth goes through cycles. We are not the only people or creatures that have seen this happen. This isn't the first time that things have happened and they have proven that with the thing in Antarctica. I know that Venus has global warming but our planet has regulated. I am also a Christian so I believe in creationism and not evolution so I don't believe that the planet is going to destroy itself.

\section{Factors Influencing Concern}

Related to such associations, we were interested in identifying what general personal, social, or contextual factors influenced our survey respondents in their consideration of our survey questions, even absent any indication of perceived bias in the survey measures we used. In response to open-ended questions about why they answered the survey questions as they did, several interviewees made references to Nebraska's agricultural character playing a role in their levels of concern regarding climate change:

I am slightly concerned because Nebraska is an agricultural state. Our main source of everything is farming. I am slightly concerned that there is not a lot done. Other than my family and community, we are concerned, but not everybody is concerned enough to act upon it.

You can see some of the impacts and changes. Plants that we grow in Nebraska are not the same that were growing before. Some things are dying out.

Specific reference was also made to droughts affecting Nebraska:

I think that droughts are a problem. I think that if you watch, they get worse every year. They last longer, and when I first moved to Nebraska, it didn't seem like they talked about it as much as they do now.

A few interviewees mentioned personal experiences as a frame of reference for their concern, or lack of concern, about the climate, although they were a minority. One interviewee indicated that his lack of concern for climate change was based on personal observations:

I grew up in a desert, so water conservation was sort of second in nature. But it's not everywhere I have been, but then again, growing up I was used to triple digit summers and low humidity. The first-hand in- formation and sorts of experiences I have had don't show anything like trends. I go back and look at it and it's been pretty much the same. So I don't think that, one of the problems I have is how drastic the information is being put before us, I think for sort of shock value.

Although survey responses indicated that our sample was generally concerned about climate change, none of our interviewees indicated that their concern had reached a level of alarm or anxiety. Likewise, none of the interviewees indicated that their social network or context played a significant role in their level of concern about climate change:

I laughed when I saw it [the question about social network] because most people I know don't care. It amused me not because the question is bad but because of how my friends feel-no one cares.

Some people think climate change is bogus and others do not. It's really all over the map. I personally think on average there are more people that are concerned than not concerned. ... Even if people aren't in a panic I think they are thinking about things they can do like turning off lights when they need them, and it's not just about the environment, it's about not being wasteful. I'm in the median of all those views, I don't think it's a panic situation.

\section{Discussion and Conclusion}

We were interested in exploring participant interpretations of climate change survey questions, and whether our study sample would perceive any bias or related concerns regarding survey items presented to them. Neither our survey nor interview results indicated that there were widespread concerns over bias with the sample of questions presented to them, though the possibility of bias was indicated by a small portion of survey and interview respondents, and a small, marginal $(p<$ .10) negative correlation between concern about climate change and perceptions of bias. In fact, none of the three questions designed to assess perceptions related to bias were significantly correlated with either one's own or one's social network's concern. On the other hand, our study sample was skewed in that it contained a higherthan-typical proportion of persons who indicated some concern about climate change and global warming. If the sample had included more variability, that is, more persons who disbelieved that climate change and global 
warming was a problem, we may have found stronger relationships between concern and the questions used to assess bias. Our results suggest that for those members of the public who are concerned about climate change, and are at least to some extent already scientifically or climate literate or seek to be so, concerns over bias are minimal. This seems to affirm a general assumption that greater knowledge about the issue may mitigate the salience of problems related to perceptions of trust.

Our interviews indicated that the words and questions within our survey resulted in varying cognitive associations and interpretations, and that constructs were elicited that may not have fit the intentions of the survey question writers. For example, our findings suggest no clear consensus exists on the meaning of frequently used terminology like "global warming" or "climate change" - terms that refer to concepts which are arguably fundamental to understanding the issues. In addition, use of such terms can evoke mental associations with politics, politicians, and religious beliefs. Further research could examine the extent to which variations in understandings or interpretations of climate-related terms predict beliefs and impact survey results.

Finally, relating to factors impacting levels of concern about climate change, our convenience sample of Nebraskans referenced observations of agriculture and weather (e.g., drought) as impacting their levels of concern. Nonetheless, they appeared to believe that their social networks had relatively little concern about changes that might occur due to climate change. Persons who did perceive their social networks as having concerns also indicated higher subjective knowledge. However, subjective knowledge did not predict one's own personal concern. These relationships may be worthy of further study. For example, they could indicate that subjective knowledge makes one more attentive to the concerns of one's social networks, increases one's perception that others will be concerned, or indicate the influence of a third variable (e.g., social discourse about climate change) impacting both. Such work would build off previous research conducted on how social networks impact individual engagement in climate change (Lorenzoni et al. 2007; Robelia et al. 2011).

It should be noted that our study participants were not a representative sample, and our findings should thus not be reflective of the state of Nebraska or other populations. Further research is thus needed using a representative study population. Specifically, perceived bias in survey items should be measured among a study population that does not have the relatively high rates of concern about climate change as ours did. This is particularly important since some of our interview findings suggest that individuals who do not share those concerns may be more critical or more likely to perceive bias in survey measures than those who do.

\section{Acknowledgments}

We would like to thank Holly Lussenden and Joseph Robine, research assistants at the University of Nebraska-Lincoln School of Natural Resources, for their assistance with this research project, and Alan Tomkins of the University of Nebraska Public Policy Center for his helpful comments on this paper. We would also like to thank and acknowledge the colleagues and partners we engaged with at both Kansas State University and the University of Nebraska-Lincoln whose work in climate science and climate education helped spur these research activities, including Roger Bruning, Amber Campbell-Hibbs, Ben Champion, Daniel Devlin, John Harrington Jr., Michael Hayes, Ken Hubbard, Eric Hunt, Daniel Kahl, Jan Middendorf, Gwen Nugent, Tapan Pathak, Chuck Rice, Martha Shulski, Jacqueline Spears, Tim Steffensmeier, and Natalie Umphlett. Additionally, we would like to thank the staff at the University of Nebraska State Museum at Morrill Hall, the coordinators of the annual Dinosaurs and Disasters event, and the individuals who provided their time and insight to our survey and interview. This work was partially supported by supplemental funding from the National Science Foundation (NSF-DBI-CCEP-1135395, supplemental to NSF-DUE-CCEP-1043393). The views eXpressed in this article are the authors' only, and do not represent the NSF, the University of Nebraska, or any of the above-mentioned individuals or entities.

\section{Appendix: Surveys Reviewed}

Anable et al. (2006)

Armel et al. (2011)

Bostrom et al. (1994)

Bray and von Storch (2007)

Dunlap et al. (2000)

ecoAmerica and Strategic Business Insights (2011)

Kellstedt et al. (2008)

Leiserowitz (2006)

Leiserowitz et al. (2010) 
Li et al. (2009)

Maibach et al. (2009)

Pew Research Center for the People and the Press (2009a, 2009c)

Vedlitz et al. (2008, 2010)

Vogt et al. (2008)

Tarik Abdel-Monem, University of Nebraska Public Policy Center, 215 Centennial Mall South, Suite 401, Lincoln NE 68588-0228, tabdelmonem2@unl.edu

Lisa M. PytlikZillig, University of Nebraska Public Policy Center, 215 Centennial Mall South, Suite 401, Lincoln NE 68588-0228

Tonya K. Bernadt, University of Nebraska-Lincoln, National Drought Mitigation Center, 3310 Holdrege Street, Lincoln NE 68583

Nicole A. Wall, University of Nebraska-Lincoln, National Drought Mitigation Center, 3310 Holdrege Street, Lincoln NE 68583

\section{References}

Anable, Jillian, Ben Lane, and Tanika Kelay. 2006. An Evidence Base Review of Public Attitudes to Climate Change and Transport Behaviour. London: Department for Transport.

Armel, K. Carrie, Katy Yan, Annika Todd, and Thomas N. Robinson. 2011. "The Stanford Climate Change Behavior Survey (sccBs): Assessing Greenhouse Gas Emissions-Related Behaviors in Individuals and Populations." Climatic Change 109 (3-4): 671-94.

Backus, George, Thomas Lowry, Drake Warren, Mark Ehlen, Geoffrey Klise, Verne Loose, Len Malczynski, Rhonda Reinert, Kevin Stamber, Vince Tidwell, Vanessa Vargas, and Aldo Zagonel. 2010. Assessing the Near-Term Risk of Climate Uncertainty: Interdependencies among the US States. Sandia National Laboratories Report SAND2010-2052. Albuquerque NM: Sandia National Laboratories.

Bord, Richard J., Ann Fisher, and Robert E. O’Connor. 1998. "Public Perceptions of Global Warming: United States and International Perspectives." Climate Research 11 (1): 75-84.

Bostrom, Ann, M. Granger Morgan, Baruch Fischhoff, and Daniel Read. 1994. "What Do People Know about Global Climate Change? 1. Mental Models.” Risk Analysis 14 (6): 959-70.

Braman, Donald, Dan H. Kahan, Maggie Wittlin, Paul Slovic, Lisa Larrimore Ouellette, and Gregory N. Mandel. 2011. The Tragedy of the Risk-Perception Commons: Culture Conflict, Rationality Conflict, and Climate Change. Washington DC: GW Law Faculty Publications and Other Works, http://scholarship.law.gwu.edu/faculty_publications/213/.

Bray, Dennis, and Hans von Storch. 2007. The Perspectives of Climate Scientists on Global Climate Change. GKss-
Forschungszentrum, Bibliothek, http://news.heartland .org/sites/all/modules/custom/heartland_migration/files /pdfs/21803.pdf.

Brechin, Steven R. 2003. "Comparative Public Opinion and Knowledge on Global Climatic Change and the Kyoto Protocol: The US versus the World?" International Journal of Sociology and Social Policy 23 (10): 106-34.

Carvalho, Anabela. 2007. "Ideological Cultures and Media Discourses on Scientific Knowledge: Re-Reading News on Climate Change." Public Understanding of Science 16 (2): 223-43.

CDC, EPA, NOAA, and AWWA (Centers for Disease Control and Prevention, Environmental Protection Agency, National Oceanic and Atmospheric Agency, and American Water Works Association). 2010. When Every Drop Counts: Protecting Public Health during Drought Conditions-A Guide For Public Health Professionals. Atlanta GA: US Department of Health and Human Services.

DeMaio, Theresa J., and Jennifer M. Rothgeb. 1996. "Cognitive Interviewing Techniques: In the Lab and in the Field." In Answering Questions: Methodology for Determining Cognitive and Communicative Processes in Survey Research, ed. Norbert Schwarz and Seymour Sudman, 177-95. San Francisco: JosseyBass.

Democratic National Committee. 2012. 2012 Democratic National Platform: Moving American Forward. Washington DC: Democratic National Committee, http://www.democrats .org/democratic-national-platform.

Dietz, Thomas, Amy Dan, and Rachael Shwom. 2007. "Support for Climate Change Policy: Social Psychological and Social Structural Influences." Rural Sociology 72 (2): 185-214.

Diggs, David M. 1991. "Drought Experience and Perception of Climatic Change among Great Plains Farmers." Great Plains Research 1 (1): 114-32.

Dunlap, Riley E., George Gallup, and Alec Gallup. 1993. Health of the Planet: Results of a 1992 International Environmental Opinion Survey of Citizens in 24 Nations. Princeton NJ: George H. Gallup International Institute.

Dunlap, Riley E., Kent D. Van Liere, Angela G. Mertig, and Robert Emmet Jones. 2000. "New Trends in Measuring Environmental Attitudes: Measuring Endorsement of the New Ecological Paradigm: A Revised NeP Scale.” Journal of Social Issues 56 (3): 425-42.

Easterling, William E., III, Pierre R. Crosson, Norman J. Rosenberg, Mary S. McKenney, Laura A. Katz, and Kathleen M. Lemon. 1993. "Paper 2. Agricultural Impacts of and Responses to Climate Change in the Missouri-IowaNebraska-Kansas (MINk) Region.” Climatic Change 24 (1-2): 23-61.

ecoAmerica and Strategic Business Insights. 2011. Summary Report: The American Climate and Environmental Values Survey. Washington DC, http://ecoamerica.org/sites/default /files/press/ACEVs\%2OReport\%2OFinal\%2Oweb.pdf.

Egan, Patrick J., and Megan Mullin. 2012. “Turning Personal Experience into Political Attitudes: The Effect of Local 
Weather on Americans' Perceptions about Global Warming." Journal of Politics 1 (1): 1-14.

Energy Center of Wisconsin. 2008. Climate Change and Energy: Public Opinion and the Capacity for Action, 1-2. Madison: Energy Center of Wisconsin.

EPA (US Environmental Protection Agency). 1998. Climate Change and Nebraska. Washington DC: US Environmental Protection Agency.

Forsyth, B., and Judith T. Lessler. "Cognitive Laboratory Methods: A Taxonomy." In Measurement Errors in Surveys, ed. Paul Biemer, Robert M. Groves, Lars E. Lyberg, Nancy A. Mathiowetz, and Seymour Sudman, 173:393-418. Hoboken NJ: Wiley, 2011.

Fowler, Floyd J. 1995. Improving Survey Questions: Design and Evaluation, vol. 38. Thousand Oaks cA: Sage.

Fowler, Floyd J. 2008. Survey Research Methods, vol. 1. Thousand Oaks CA: Sage.

Frederick, Kenneth D. 1993. "Paper 4. Climate Change Impacts on Water Resources and Possible Responses in the MINK Region." Climatic Change 24 (1-2): 83-115.

GCRP (US Global Change Research Program). 2009. Global Climate Change Impacts in the US. Washington DC: US Global Change Research Program.

Glaser, Barney G. 1978. Theoretical Sensitivity: Advances in the Methodology of Grounded Theory, vol. 2. Mill Valley cA: Sociology Press.

Greenstone, Michael, and Olivier Deschenes. 2006. The Economic Impacts of Climate Change: Evidence from Agricultural Profits and Random Fluctuations in Weather. FEEM Working Paper No. 6.2006, http://papers.ssrn.com/sol3/papers .cfm?abstract_id=876929.

Hamilton, Lawrence C., and Barry D. Keim. 2009. "Short Communication Regional Variation in Perceptions about Climate Change." International Journal of Climatology 2009, http://pubpages.unh.edu/ lch/Hamilton_climate _perception.pdf.

Harris, Louis, and Associates. 1989. Public and Leadership Attitudes to the Environment in Four Continents: A Report of a Survey in 14 Countries. New York: Louis Harris and Associates.

Harris, Tom. "Yale/George Mason University Climate Poll Just Another Biased Survey Promoting the Climate Scare." Frontier Centre, October 12, 2012. http://www.fcpp.org /blog/yalegeorge-mason-university-climate-poll-just -another-biased-survey-promoting-the-climate-scare/.

High Plains Regional Climate Center. n.d. Climate Change on the Prairie: A Basic Guide to Climate Change in the High Plains Region. Lincoln NE: High Plains Regional Climate Center.

Hoffman, Andrew. 2011. "The Culture and Discourse of Climate Skepticism." Strategic Organization 9 (1): 77-84.

IPCC. 2007. "Summary for Policymakers." In Climate Change 2007: The Physical Science Basis. Contribution of Working Group I to the Fourth Assessment Report of the Intergovernmental Panel on Climate Change, ed. Susan Solomon, Dahe Qin, Martin Manning, Melinda Marquis, Kristen
Averyt, Melinda Tignor, Henry Leroy Miller, and Zhenlin Chen, 1-18. Cambridge: Cambridge University Press.

Jobe, Jared B., and David J. Mingay. 1991. "Cognition and Survey Measurement: History and Overview." Applied Cognitive Psychology 5 (3): 175-92.

Joireman, Jeff, Heather Barnes Truelove, and Blythe Duell. 2010. "Effect of Outdoor Temperature, Heat Primes and Anchoring on Belief in Global Warming." Journal of Environmental Psychology 30 (4): 358-67.

Kahan, Dan M., Donald Braman, John Gastil, Paul Slovic, and C. K. Mertz. 2007. "Culture and Identity Protective Cognition: Explaining the White Male Effect in Risk Perception.” Journal of Empirical Legal Studies 4 (3): 465-505.

Karl, T., J. Melillo, and T. Peterson. 2009. Global Climate Change Impacts in the United States (US Global Change Research Program). New York: Cambridge University Press.

Kasemir, Bernd, Urs Dahinden, Åsa Gerger Swartling, Ralf Schüle, David Tabara, and Carlo C. Jaeger. 200o. "Citizens' Perspectives on Climate Change and Energy Use." Global Environmental Change 10 (3): 169-84.

Kellstedt, Paul M., Sammy Zahran, and Arnold Vedlitz. 2008. "Personal Efficacy, the Information Environment, and Attitudes toward Global Warming and Climate Change in the United States." Risk Analysis 28 (1): 113-26.

Kelly, David L., Charles D. Kolstad, and Glenn T. Mitchell. 2005. "Adjustment Costs from Environmental Change." Journal of Environmental Economics and Management 50 (3): 468-95.

Kempton, Willett. 1991. "Lay Perspectives on Global Climate Change." Global Environmental Change 1 (3): 183-208.

Kempton, Willett. 1997. "How the Public Views Climate Change." Environment: Science and Policy for Sustainable Development 39 (9): 12-21.

Kempton, Willett, James S. Boster, and Jennifer A. Hartley. 1996. Environmental Values in American Culture. Cambridge MA: MIT Press.

Kohut, Andrew. 2010. "Letter: Views on Climate Change: What the Polls Show." New York Times, June 13. http://www .nytimes.com/2010/o6/14/opinion/l14climate.html.

Krosnick, Jon. 2010. “The Climate Majority.” New York Times, June 8. http://www.nytimes.com/2010/o6/o9 /opinion/ogkrosnick.html?_r=o.

Krosnick, Jon A., Allyson L. Holbrook, Laura Lowe, and Penny S. Visser. 2006. "The Origins and Consequences of Democratic Citizens' Policy Agendas: A Study of Popular Concern about Global Warming." Climatic Change 77 (1-2): $7-43$.

Krosnick, Jon A., Allyson L. Holbrook, and Penny S. Visser. 2000. "The Impact of the Fall 1997 Debate about Global Warming on American Public Opinion." Public Understanding of Science 9 (3): 239-6o.

Leiserowitz, Anthony A. 2004. "Day After Tomorrow: Study of Climate Change Risk Perception.” Environment: Science and Policy for Sustainable Development 46 (9): 22-39. 
Leiserowitz, Anthony. 2005. "American Risk Perceptions: Is Climate Change Dangerous?” Risk Analysis 25 (6): 1433-42.

Leiserowitz, Anthony. 2006. "Climate Change Risk Perception and Policy Preferences: The Role of Affect, Imagery, and Values." Climatic Change 77 (1-2): 45-72.

Leiserowitz, Anthony A., Edward W. Maibach, Connie RoserRenouf, Nicholas Smith, and Erica Dawson. 2012. "Climategate, Public Opinion, and the Loss of Trust." American Behavioral Scientist 57 (6): 818-37.

Leiserowitz, Anthony, and Nicholas Smith. 2010. Knowledge of Climate Change across Global Warming's Six Americas. New Haven ст: Yale University, Yale Project on Climate Change Communication. http://environment.yale.edu /climate-communication/article/knowledge-of-climate -change-across-global-warmings-six-americası.

Leiserowitz, Anthony, Nicholas Smith, and Jennifer Marlon. 2010. Americans' Knowledge of Climate Change. New Haven ст: Yale University, Yale Project on Climate Change Communication.

Li, Hui, Hank C. Jenkins-Smith, Carol L. Silva, Robert P. Berrens, and Kerry G. Herron. 2009. "Public Support for Reducing US Reliance on Fossil Fuels: Investigating Household Willingness-to-Pay for Energy Research and Development." Ecological Economics 68 (3): 731-42.

Lichter, S. Robert. 2008. "Climate Scientists Agree On Warming, Disagree on Dangers, and Don't Trust the Media's Coverage of Climate Change." stats/George Mason University, http://stats.org/stories/2008/global_warming _survey_apr23_08.html.

Litwin, Mark S. 1995. How to Measure Survey Reliability and Validity, vol. 7. Thousand Oaks ca: Sage.

Lorenzoni, Irene, Sophie Nicholson-Cole, and Lorraine Whitmarsh. 2007. "Barriers Perceived to Engaging with Climate Change among the UK Public and their Policy Implications." Global Environmental Change 17 (3): 445-59.

Mader, Terry L., Katrina L. Frank, John A. Harrington Jr., G. Leroy Hahn, and John A. Nienaber. 2009. "Potential Climate Change Effects on Warm-Season Livestock Production in the Great Plains." Climatic Change 97 (3-4): 529-41.

Maibach, Edward, Anthony Leiserowitz, Sara Cobb, Michael Shank, Kim M. Cobb, and Jay Gulledge. 2012. "The Legacy of Climategate: Undermining or Revitalizing Climate Science and Policy?" Wiley Interdisciplinary Reviews: Climate Change, no. 3: 289-95.

Maibach, Edward, Connie Roser-Renouf, and Anthony Leiserowitz. 2009. Global Warming's Six Americas 2009: An Audience Segmentation Analysis. Fairfax va: George Mason University, Center for Climate Change Communication. http://www.americanprogress.org/wp-content/uploads /issues/2009/05/pdf/6americas.pdf.

Malka, Ariel, Jon A. Krosnick, and Gary Langer. 2009. "The Association of Knowledge with Concern about Global Warming: Trusted Information Sources Shape Public Thinking." Risk Analysis 29 (5): 633-47.

McCright, Aaron M., and Riley E. Dunlap. 2011. "The Politiciza- tion of Climate Change and Polarization in the American Public's Views of Global Warming, 2001-2010." Sociological Quarterly 52 (2): 155-94.

Morello, Lauren. 2010. "Stolen E-Mails Sharpen a Brawl between Climate Scientists and Skeptics." New York Times, November 24, http://www.nytimes.com/cwire/2009/11/24/24 climatewire-stolen-e-mails-sharpen-a-brawl-between -clima-19517.html.

Morgan, M. Granger, Baruch Fischhoff, Ann Bostrom, and Cynthia J. Atman. 2001. Risk Communication: A Mental Models Approach. Cambridge: Cambridge University Press.

NASA (National Aeronautics and Space Administration). 2008. "What's In a Name? Global Warming vs. Climate Change." NASA, http://www.nasa.gov/topics/earth/features/climate _by_any_other_name.html.

NCADAC (National Climate Assessment and Development Advisory Committee). 2013. NCADAC Draft Climate Assessment Report, http://ncadac.globalchange.gov/download /NCAJan11-2013-publicreviewdraft-fulldraft.pdf.

O'Connor, Robert E., Richard J. Bord, Brent Yarnal, and Nancy Wiefek. 2002. "Who Wants to Reduce Greenhouse Gas Emissions?” Social Science Quarterly 83 (1): 1-17.

Ojima, Dennis, Jill Lackett, and the Central Great Plains Steering Committee and Assessment Team. 2002. Preparing for a Changing Climate: The Potential Consequences of Climate Variability and Change, Report for the US Global Change Research Program. Fort Collins: Colorado State University.

Oksenberg, Lois, Charles Cannell, and Graham Kalton. 1991. "New Strategies for Pretesting Survey Questions." Journal of Official Statistics 7 (3): 349-65.

Pew Research Center for the People and the Press. 2009a. May 2009 General Public Science Survey Final Topline. Washington DC: Pew Research Center, http://www.people-press .org/files/legacy-questionnaires/528.pdf.

Pew Research Center for the People and the Press. 2009b. Public Praises Science; Scientists Fault Public, Media. Section 4: Scientists, Politics and Religion. Washington DC: Pew Research Center, http://www.people-press.org/2009/o7/o9 /section-4-scientists-politics-and-religion/.

Pew Research Center for the People and the Press. 2009c. Survey Topline Results Survey of 25 Nations. Washington DC: Pew Research Center, http://www.pewglobal.org/files/2009/o7 /Pew-Global-Attitudes-Spring-2009-Report-1-topline.pdf.

PewResearchCenterforthePeopleandthePress.2010.LittleChange in Opinions about Global Warming. Washington DC: Pew Research Center, http://www.people-press.org/2010/10/27 /little-change-in-opinions-about-global-warming/.

Pew Research Center for the People and the Press. 2012. More Say There Is Solid Evidence of Global Warming. Washington DC: Pew Research Center, http://www .people-press.org/2012/10/15/more-say-there-is-solid -evidence-of-global-warming/.

Pexton, Patrick. 2012. "Was Climate-Change Poll Biased?" Washington Post, July 9, http://www.washingtonpost .com/blogs/omblog/post/was-climate-change-poll -biased/2012/o7/og/gJQAYreeYW_blog.html. 
Pielke, Roger. 2012. "NOAA Climate Survey-A Biased Approach to Assess nOAA Employees' View of Climate Science." Climate Science: Roger Pielke Sr., February 3, http://pielkeclimatesci.wordpress.com/2012/02/03/noaa -climate-survey-a-biased-approach-to-assess-noaa -employeess-view-of-climate-science/.

Read, Daniel, Ann Bostrom, M. Granger Morgan, Baruch Fischhoff, and Tom Smuts. 1994. "What Do People Know about Global Climate Change? 2. Survey Studies of Educated Laypeople." Risk Analysis 14 (6): 971-82.

Reilly, John, F. Tubiello, B. McCarl, D. Abler, R. Darwin, K. Fuglie, S. Hollinger, et al. 2003. "US Agriculture and Climate Change: New Results.” Climatic Change 57 (1-2): 43-67.

Republican National Committee. 2012. We Believe in America 2012: Republican Platform. Washington DC: Republican National Committee, http://www.gop.com/wp-content /uploads/2012/o8/2012GOPPlatform.pdf.

Robelia, Beth A., Christine Greenhow, and Lisa Burton. 2011. "Environmental Learning in Online Social Networks: Adopting Environmentally Responsible Behaviors.” Environmental Education Research 17 (4): 553-75.

Rosenberg, Stacy, Arnold Vedlitz, Deborah F. Cowman, and Sammy Zahran. 2010. "Climate Change: A Profile of US Climate Scientists' Perspectives." Climatic Change 101 (34): 311-29.

Rosenzweig, Cynthia. 1989. "Potential Effects of Climate Change on Agricultural Production in the Great Plains: A Simulation Study." In The Potential Effects of Global Climate Change on the United States: Report to Congress, ed. Joel B. Smith and Dennis A. Tirpak, 93-122. Washington DC: US Environmental Protection Agency, Office of Policy, Planning, and Evaluation, Office of Research and Development.

Sandell, Clayton. 2007. "Report: Big Money Confusing Public on Global Warming." $A B C$ News, January 3. http://abcnews .go.com/Technology/Business/story?id=2767979\&page $=1$.

Schumacher-Matos, Edward. 2011. "Global Warming vs. Climate Change: Does it Make a Difference?” National Public Radio, November 17. http://www.npr.org/blogs/ombudsman /2011/11/17/142418671/global-warming-vs-climate-change -does-it-make-a-difference.

Shwom, Rachael, Amy Dan, and Thomas Dietz. 2008. “The Effects of Information and State of Residence on Climate Change Policy Preferences." Climatic Change 9o (4):343-58.

Solomon, Lawrence. 2010. "Financial Post Comment: Global Warming Strategist Scores New York Times Coup." Financial Post, June 21. http://opinion.financialpost.com/2010 /o6/21/lawrence-solomon-global-warming-strategist -scores-new-york-times-coup/.
Spence, A., Wouter Poortinga, Catherine Butler, and Nicholas Frank Pidgeon. 2011. "Perceptions of Climate Change and Willingness to Save Energy Related to Flood Experience." Nature Climate Change 1 (1): 46-49.

Strauss, Anselm. 1987. Qualitative Analysis for Social Scientists. Cambridge: Cambridge University Press.

Strauss, Anselm, and Juliet Corbin. 1990. Basics of Qualitative Research: Grounded Theory Procedures and Techniques. Thousand Oaks ca: Sage.

Tourangeau, Roger. 1984. "Cognitive Sciences and Survey Methods." In Cognitive Aspects of Survey Methodology: Building a Bridge between Disciplines, ed. Thomas Jabine, Miron Straf, Judith Tanur, and Roger Tourangeau, 73-100. Washington DC: National Academy Press.

Trumbo, Craig. 1996. "Constructing climate change: claims and frames in US news coverage of an environmental issue." Public Understanding of Science 5 (3): 269-83.

Vedlitz, Arnold, Letitia Alston, B. Dan Wood, Gerald North, and Eric Lindquist. 2008. Project Final Report: Utilization of Science-Based Information on Climate Change in Decision Making and the Public Policy Process, Phase I (Project funded under award NAO3OAR4310164 from the National Oceanic and Atmospheric Administration). College Station: Texas A\&M University, Bush School of Government and Public Service.

Vedlitz, Arnold, Eric Lindquist, Xinsheng Liu, Sammy Zahran, B. Dan Wood, Letitia T. Alston, and Gerald North. 2010. Utilization of Science-Based Information on Climate Change in Decision Making and the Public Policy Process, Phase II (project funded under award NAO4OAR4600172 from the National Oceanic and Atmospheric Administration). College Station: Texas A\&M University, Bush School of Government and Public Service.

Villar, Ana, and Jon A. Krosnick. 2011. "Global Warming vs. Climate Change, Taxes vs. Prices: Does Word Choice Matter?" Climatic Change 105 (1-2): 1-12.

Vogt, Rebecca J., Randolph L. Cantrell, Miguel A. Carranza, Bruce B. Johnson, and David J. Peters. 2008. Global Climate Change: Opinions and Perceptions of Rural Nebraskans. Lincoln NE: Publications from the Center for Applied Rural Innovation (CARI).

Weingart, Peter, Anita Engels, and Petra Pansegrau. 2000. "Risks of Communication: Discourses on Climate Change in Science, Politics, and the Mass Media." Public Understanding of Science 9 (3): 261-83.

Wood, B. Dan, and Arnold Vedlitz. 2007. "Issue Definition, Information Processing, and the Politics of Global Warming." American Journal of Political Science 51 (3): 552-68. 